\title{
KEBUTUHAN PENDAMPINGAN PASTORAL UNTUK MENGATASI KECANDUAN GAME ONLINE REMAJA DI JEMAAT GMAHK PIONEER TOMPASO
}

\author{
Micle Edwin Tumundo, Rudolf Sagala, Stimson Hutagalung \\ Program Pascasarjana Magister Filsafat Universitas Advent Indonesia \\ Tumundomicle73@gmail.com
}

\begin{abstract}
The purpose of this study was to determine the importance of pastoral care for church youth who are addicted to online games. The method used is a survey with data collection techniques using a questionnaire with non-probability sampling. The number of questionnaires was collected from 66 respondents among the 130 congregations. The research subjects were the Pioneer Tompaso Seventh-day Adventist Church in Jl. Pemuda Kamanga 2 Village, Tompaso District, Minahasa Regency, North Sulawesi Province. The data were analyzed according to the five respondents' preferences for the answers to the questionnaire, ranging from strongly agree to disagree strongly. The results show that $75.8 \%$ agree and strongly agree that online games have a terrible impact on their future and $71.4 \%$ want to get rid of online game addiction. The results also show that $62.1 \%$ of respondents need pastoral assistance and trust the pastor's guidance and advice.
\end{abstract}

Keywords: Pastoral Assistence, Addiction, online gaming.

\begin{abstract}
Abstrak. Tujuan penelitian ini adalah untuk mengetahui pentingnya pendampingan pastoral bagi remaja gereja yang kecanduan game online. Metode yang di gunakan adalah survey dengan teknik pengumpulan data menggunakan kuesioner dengan non probability sampling. Jumlah kuesioner yang terkumpul adalah 66 dari populasi Jemaat yang aktif 130 orang. Subyek penelitian adalah Jemaat Gereja Masehi Advent Hari Ketujuh Pioneer Tompaso Jl. Pemuda Desa Kamanga 2 Kecamatan Tompaso Kabupaten Minahasa Provinsi Sulawesi Utara. Data di analisa sesuai dengan 5 preferensi responden atas jawaban kuisioner mulai dari sangat setuju sampai pada sangat tidak setuju. Hasil menunjukan $75.8 \%$ setuju dan sangat setuju bahwa game online berdampak buruk pada masa depan mereka dan $71.4 \%$ berkeinginan untuk terlepas dari kecanduan game online. Hasil juga menunjukan bahwa $62.1 \%$ responden membutuhkan pendampingan pastoral dan percaya kepada bimbingan dan nasehat pendeta.
\end{abstract}

Kata Kunci: Pendampingan Pastoral, Kencanduan, game online.

Berbagai hal dalam kehidupan manusia memunculkan kompleksitas permasalahan hidup. Setiap manusia mempunyai permasalahan yang berbeda-beda, masing masing memerlukan solusi, baik melalui diri sendiri, maupun pendampingan dari orang lain. Pendampingan dari orang lain dapat 
membantu menguraikan kompleksitas permasalahan tersebut (Nugroho, 2017).

Pendampingan adalah sebuah aktifitas memberikan bantuan kepada orang yang membutuhkan. Orang yang mendampingi disebut dengan pendamping. Antara yang mendampingi dan yang di dampingi terjadi interaksi yang setara atau sejajar. Dengan demikian menurut Beek, istilah pendampingan berarti kegiatan menjadi mitra dalam: bahu-membahu, menemani, membagi dengan tujuan saling menumbuhkan (Hutagalung, 2021).

Pelayanan pastoral Kristen dapat berupa: mendengarkan, mendorong, mengunjungi, keramahan, memberi advokasi, pendampingan, berteman, merayakan, membantu, berdoa, menghibur, memampukan (British \& Society, 2000). Lebih lanjut Hutagalung mangatakan pastoral berasal dari kata "pastor" yang memilki arti gembala. Tanggung jawab seorang gembala secara tradisional adalah memelihara dan merawat umat gembalaannya. Menurut Kamus Merriam-Webster, arti pastoral adalah "of or relating to spiritual care or guidance especially of a congregation"

Dalam pendampingan kepada pemuda remaja keristen, gereja menghadapi tantangan yang serius seiring dengan kemajuan teknologi digital. Permainan yang sebelumnya berhubungan dengan gerakan fisik, perlahan tapi pasti berpindah ke permainan digital yang menggunakan perangkat komputer, smartphone baik offline maupun online. Menurut Eryzal Novrialdy, remaja yang tumbuh dan berkembang pada era milenium saat ini akan bersentuhan dengan kecanggihan-kecanggihan teknologi yang memudahkan 
untuk mendapatkan berbagai informasi yang dibutuhkan remaja saat ini, yang juga disebut generasi post-millenials. Salah satu cirinya yaitu tumbuh dengan teknologi yang sangat mudah untuk diakses, sehingga hal tersebut membuat remaja saat ini dapat juga dikatakan sebagai generasi yang paling memahami teknologi (Novrialdy, 2019).

Game online adalah permainan komputer yang dimainkan oleh lebih dari satu pemain yang memanfaatkan media jaringan komputer (LAN atau Internet). Perusahaan penyedia jasa online atau dikenal juga dengan warnet (warung internet), warnet tidak hanya dijumpai di perkotaan saja tetapi sudah banyak tersedia di desa-desa saat ini (Ali et al., 2019). Game online juga dapat dimainkan di smartphone melalui jaringan nirkabel.

Kecanduan adalah sebuah prilaku yang dipengaruhi oleh beberapa faktor, baik secara fisik fisiologis maupun psikologis. Menurut sejarah, kecanduan telah didefinisikan hanya untuk suatu hal yang berkenaan dengan zat adiktif (misalnya alkohol, tembakau, obat-obatan) yang masuk melewati darah kemudian ke otak, dan dapat merubah komposisi kimia di otak. Arti kecanduan sendiri berkembang, sehingga istilah bukan hanya melekat pada obat-obatan tetapi juga melekat pada aktifitas atau hal tertentu yang dapat membuat seseorang ketergantungan secara fisik maupun psikologi (Psychologymania, 2008).

Game online berdampak positif jika dimanfaatkan untuk hiburan, yang akan mengurangi rasa penat dan stres. Namun fakta mengatakan saat ini, game online banyak dimainkan secara berlebihan bahkan digunakan sebagai tempat pelarian dari realitas kehidupan, sehingga yang terjadi adalah 
kecanduan. Kecanduan tersebut pada remaja akan berdampak pada beberapa aspek kehidupan, seperti aspek kesehatan, aspek psikologis, aspek akademik, aspek sosial dan aspek keuangan (Novrialdy, 2019).

Ada banyak penelitian untuk mempelajari bagaimana video game bisa menjadi sumber kecanduan. Menurut sebuah survei Lu dan Wang pada tahun 2008, 60\% responden mengatakan bahwa mereka bermain game online setiap hari dan $33 \%$ mengatakan bahwa mereka menghabiskan lebih dari 3 jam per sesi permainan (Hermawan, 2019).

Pertemanan mempengaruhi kecanduan game online karena selain adanya fasilitas chat room pada bebrapa plat form online gaming yang memungkinkan sesama pengguna berbincang bincang sambil bermain. Bahkan para gamer kemudian dapat membuat satu komunitas sesama gamer lewat whatsapp group dimana mereka dapat berkomunikasi setiap saat sehingga memotivasi mereka untuk terus bermain.

Peneliti memilih Gereja Masehi Advent Hari Ketujuh Jemaat Pioneer Tompaso Jl Pemuda Desa Kamanga 2 Tompaso sebagai subyek penelitian. Di Jemaat tersebut memiliki jumlah anggota jemaat milenial di atas 50\% sehingga ada potensi penggunaan game online sebagai salah satu pilihan rekreasi. Penelitian ini akan memberikan perkiraan mengenai salah satu solusi dalam menghadapi kecanduan game online, dengan mengadakan pendampingan pastoral.

Dari beberapa penelitian sebelumnya yang berhubungan dengan pendampingan pastoral dan konseling pastoral, membahas tentang dampak dan saran penanganan. Sebagai contoh penelitian sebelumnya tentang 
Pendampingan Pastoral Terhadap Perilaku Anak Sekolah Minggu Akibat Ketergantungan Penggunaan Gadget dengan tujuan penelitian mengkaji perilaku anak sekolah minggu akibat ketergantungan pengunaan gadget. (Agata, 2017).

Selanjutnya penelitian yang membahas tentang Konseling Pastoral Krisis dengan tujuan penelitian adanya kesadaran orang tua dan gereja akan kecanduan gadget merupakan isu penting yang perlu segera mendapatkan penanganan (Kurniawan, 2020).

Berbeda dengan kedua penelitian sebelumnya penelitian ini bertujuan, untuk menemukan apakah signifikan atau tidak kebutuhan pendampingan pastoral pada remaja yang kecanduan game online. Penelitian ini akan memberikan perkiraan mengenai salah satu solusi dalam menghadapi kecanduan game online adalah mengadakan pendampingan pastoral kepada pemain game online.

Definisi pemuda menurut kamus besar bahasa indonesia pemuda/pe·mu.da/ orang muda laki-laki; remaja; teruna (Setiawan, 2021). Pemuda adalah seorang laki-laki atau perempuan yang akan mencapai tahap usia dewasa, baik secara fisik maupun mental.

Pemuda sebagai agen perubahan, juga adalah sebagai agen kontrol sosial menjadi sebuah amunisi dari maju mundurnya sebuah bangsa yang senantiasa siap untuk selalu mengambil peran dan menuntut sumbangsihnya demi kemajuan kehidupan berbangsa dan bernegara (Januarharyono, 2019). Dapat dibayangkan apa yang akan terjadi bila pemuda yang adalah aset bangsa, pada saat yang sama pemuda keristen adalah juga aset gereja, 
terjebak dalam kecanduan aktifitas yang tidak bermanfaat bagi masa depan mereka.

\section{METODE}

Metode penelitian yang di gunakan dalam penelitian ini adalah survei. Untuk mengumpulkan informasi berbentuk opini dari sejumlah besar orang terhadap topik atau isu-isu tertentu. Sampel penelitian diambil dengan teknik sampling kuota, yaitu menentukan sampel dari populasi yang mempunyai ciriciri tertentu sampai jumlah (kuota) yang diinginkan (Siswanto et al., 2021).

Tujuan utama dari survei adalah mengetahui gambaran umum karakteristik dari populasi (Untari, 2018), dijelaskan pula mengenai populasi dan sampel penelitian. Pada pembicaraan populasi ditunjukkan wilayah mana dijadikan penelitian dan bagaimana representasi sampel penelitian, bagaimana pertimbangan-pertimbagan pengambilan sampel tersebut dan teknik sampling apa yang digunakan (Nofianti \& Qomariah, 2017).

Peneliti mengadakan survey melalui kuesioner dengan target responden 50\% yaitu 66 anggota jemaat dari Jumlah anggota jemaat yang aktif di Gereja Masehi Advent Hari Ketujuh Jemaat Pioneer Tompaso Jl. Pemuda Desa Kamanga 2 Tompaso yang adalah 130 anggota. Dari kuisioner yang sudah disebar ke semua anggota, peneliti menetapkan kuota penerimaan jawaban akan di tutup jika 65 responden atau 50\% dari jumlah populasi telah masuk. 


\section{Profil Responden}

Dari hasil penerimaan kuisioner melalui link Google Form, ternyata yang memberikan jawaban ada 66 responden dari 65 yang dibutuhkan, lebih 1 responden. Karena selisinya tidak signifikan maka tetap diterima.

Gambar 1. Jenis Kelamin Responden

\begin{tabular}{|l|l|}
\hline Identitas \\
\hline Jenis Kelamin \\
66 responses \\
\end{tabular}

Dari hasil responden menunjukan, 53\% yang mengisi angket adalah perempuan dan sisanya $47 \%$ adalah laki laki.

Gambar 2. Usia Responden

\begin{tabular}{|l|l|}
\hline Usia Responden \\
66 responses
\end{tabular}


Data menunjukan dari 6 klasifikasi umur yang ditentukan, yang mengisi angket tertinggi usia 10-17 tahun 43,9\%, kedua usia 18-25 tahun $28,8 \%$ dan di urutan ke tiga adalah kelompok usia 36-45 tahun 9,15\%. Sisanya tidak signifikan. Artinya yang mengisi angket terbanyak adalah remaja dan pemuda $10-25$ tahun $77,7 \%$ dan selanjutnya kelompok usia yang diperkirakan sebagai orang tua muda dengan usia 36-45. tahun $9.1 \%$.

\section{Pendapat Responden Tentang Pendampingan Pastoral dan Kecanduan game online}

Peneliti membuat 4 pernyataan yang diajukan kepada responden untuk menguji pandangan mereka tentang kecanduan game online dan pentingnya pendampingan pastoral dalam mengatasinya: 1) Kecanduan online game berdampak negatif pada masa depan saya. 2) Saya ingin terlepas dari kecanduan online game. 3) Saya membutuhkan pendampingan untuk mengatasi kecanduan online game. 4) Saya percaya pada nasehat dan bimbingan pendeta.

Gambar 3. Persepsi Responden Terhadap Dampak Negatif Game Online

Kecanduan game online berdampak negatif pada masa depan saya.

66 responses

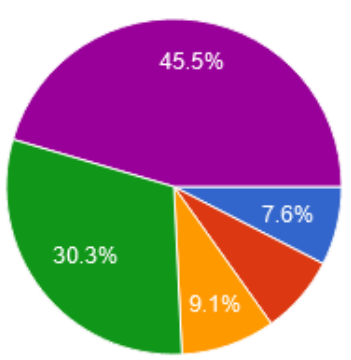

Sangat Tidak Setuju

Tidak Setuju

Netral

Setuju

Sangat Setuju 
Pada pernyataan pertama ini, $75,8 \%$ menyatakan setuju dan sangat setuju bahwa kecanduan game online berdampak negatif pada masa depan. Hal ini sesuai dengan observasi yang dilakukan bahwa pemuda disetiap kebaktian gereja lebih konsentrasi ke gadget daripada pembahasan Firman Tuhan atau khotbah bahkan ada yang sibuk bermain game online.

Gambar 4. Persepsi Responden terhadap Keinginan untuk Terlepas dari Kecanduan Game Online

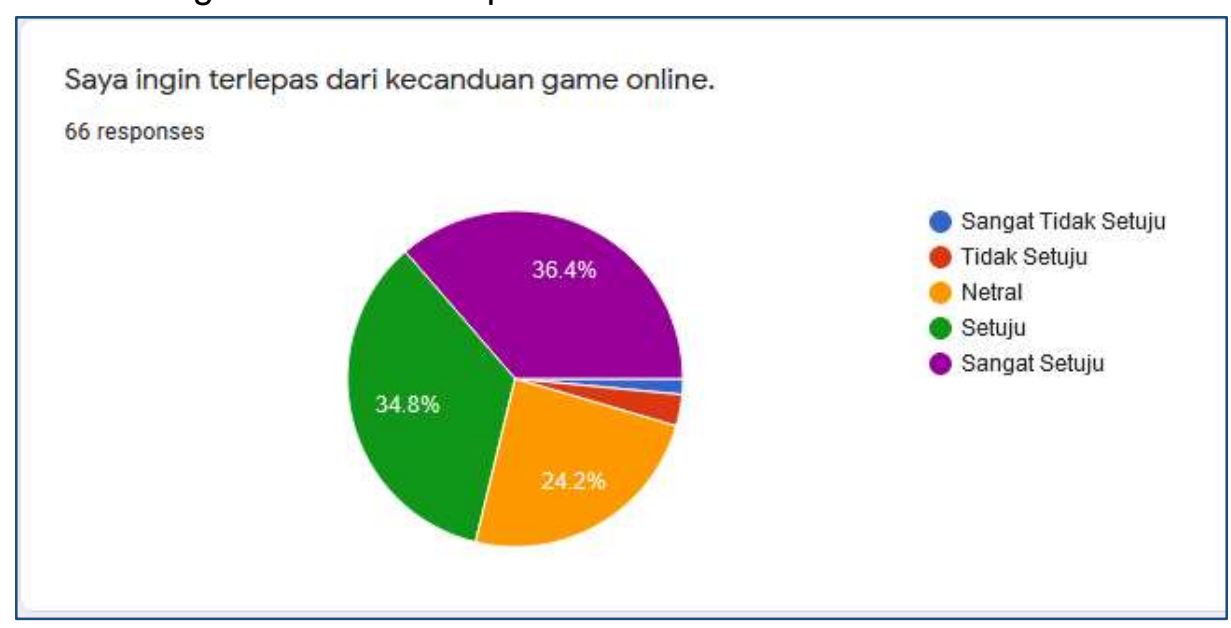

Pernyataan kedua menunjukan bahwa, jika kecanduan game online, $71,4 \%$ dari responden setuju dan sangat setuju ingin terlepas dari kecanduan tersebut. Hasil ini memperlihatkan besarnya presentasi responden yang kecanduan game online yang ingin terlepas dari aktifitas tersebut.

Pada gambar 5 berikut $62,1 \%$ dari reposponden setuju dan sangat setuju membutuhkan pendampingan dalam mengatasi kecanduan game online. Hasil ini menunjukan bahwa untuk mengatasi masalah ini, peran pendampingan sangat dibutuhkan. 
Gambar 5. Persepsi Responden tentang Kebutuhan Pendampingan

Saya membutuhkan pendampingan untuk mengatasi kecanduan game online.

66 responses

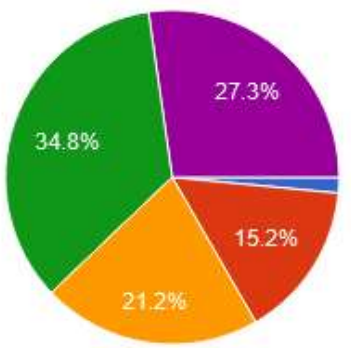

Gambar 6. Persepsi Responden tentang Kepercayaan kepada Pendampingan Pendeta

Saya percaya pada nasehat dan bimbingan pendeta.

66 responses

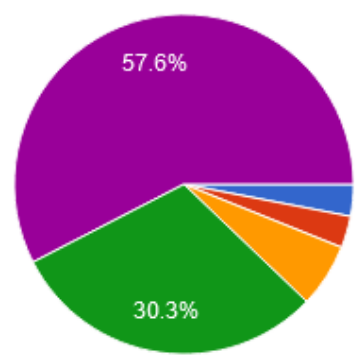

Dari jawaban responden dari pernyataan ke empat, 87,9 \% setuju dan sangat setuju "percaya pada nasehat dan bimbingan pendeta". Hasil ini menunjukan peran penting pendamping pastoral dalam hal ini pendeta. 


\section{PEMBAHASAN}

\section{Dampak Negatif Game Online}

Berdasarkan Komisi Penyiaran Indonesia tahun 2017, saat ini, banyak tayangan media, khususnya game online yang kurang mendidik dan berdampak negatif bagi anak. Beraneka ragam jenis permainan hadir di media-media tersebut yang sarat dengan kekerasan dan sadism (Sumarsih \& Nugroho, 2020). Sebagian besar dari para responden berpedapat yang sama.

Ada satu kota yang disebut Kota setia yang di tulis dalam Kitab Zakaria, kota itu adalah Yerusalem di mana dalam Zakharia 8:5 (TB) dikatakan "Dan jalan-jalan kota itu akan penuh dengan anak laki-laki dan anak perempuan yang bermain-main di situ." Konsep bermain dalam Alkitab adalah bermain di out door atau di luar ruangan. Senada dengan itu E. G. White mengatakan "Ajarkan Pelajaran-pelajaran yang Pertama di Alam Terbuka. Para ibu, biarkanlah anak-anak kecil bermain di alam terbuka; biarlah mereka mendengarkan nyanyian-nyanyian burung dan mempelajari kasih Allah sebagaimana yang dinyatakan dalam hasil kerjaNya yang indah itu" (White, 2015).

\section{Memaksimalkan Niat Berhenti Dari Aktifitas Game Online}

Memiiliki niat yang besar untuk berubah dan mulai menata kembali berbagai aktifitas harian yang terganggu akibat kecanduan game adalah salah satu solusi. Berdasarkan theory of planned behavior, terdapat salah 
satu variabel yang dapat mendukung niat seseorang untuk berperilaku, yakni perceived behavioral control. Perceived behavioral control adalah persepsi mengenai kemudahan atau kesulitan dalam melakukan perilaku dan diasumsikan merefleksikan pengalaman di masa lalu dan antisipasi mengenai halangan (Kevaladandra \& Nurmala, 2019). Ketika kita menganggap mudah mengontrol kebiasaan buruk yang sedang dilakukan maka akan memperkuat niat untuk berubah.

Sebagian besar dari responden pada penelitian ini berkeinginan atau memiliki niat untuk berhenti dari aktifitas online gaming. Ini adalah suatu hal yang positif dalam penanganan masalah tersebut. Salah satu frase dari doa yang Yesus ajarkan adalah "Lepaskanlah kami dari pada yang jahat" (Matius 6:13) menjelaskan bahwa adanya kebutuhan manusia untuk terlepas dari sesuatu yang tidak baik. Hal ini juga dapat memotivasi gereja melalui pendeta, para penatua dan majelis jemaat mencari solusi.

Tuhan Yesus tidak tinggal di surga saja tetapi merendahkan diriNya sendiri, berinkarnasi menjadi manusia (Fil 2: 5-8). Yesus dapat mengadvokasi manusia, setelah mengalami semua yang dihadapi umat manusia setiap hari. Pendeta, penatua dan gereja, harus Memiliki sikap yang sama dengan Kristus (Haines, 2011). Gereja harus menawarkan pengharapan melalui misi ini sebagai bagian dari penginjilan, supaya banyak orang yang boleh diselamatkan (Tendean et al., 2021) 


\section{Pendampingan Pastoral Sebagai Solusi}

Pendampingan Pastoral berlaku umum dan disediakan untuk semua anggota komunitas beriman. Tujuan dari pendampingan ini adalah untuk mengaktualisasikan kasih Allah dalam kehidupan komunitas beriman. Bentuk pendampingan pastoral dalam kehidupan komunitas beriman bisa berwujud (Wijayatsih, 2011).

Ibrani 10:25 (TB) “ Janganlah kita menjauhkan diri dari pertemuanpertemuan ibadah kita, seperti dibiasakan oleh beberapa orang, tetapi marilah kita saling menasihati, dan semakin giat melakukannya menjelang hari Tuhan yang mendekat." Saling menasehati adalah sebuah dasar Alkitab dalam melakukan pendampingan pastoral.

Fibry Jati Nugroho mengatakan Jemaat bukan saja sebagai obyek, tetapi juga menjadi subyek dari pelayanan pendampingan pastoral. Artinya pendampingan pastoral dilakukan oleh semua pihak dalam jemaat. Lebih lanjut beliau mengaskan Pelayanan pastoral sendiri merupakan sebuah pemeliharaan jiwa. Pemeliharaan jiwa ini termaktub di dalam terpeliharanya relasi sesama anggota jemaat, yang berujung pada sikap saling menolong dalam kehidupannya sehari-hari (Nugroho, 2017).

Dengan mengunjungi anggota jemaat pendamping pastoral dapat membangun hubungan saling membutuhkan, saling menopang, saling memberi menasehati bahkan saling mendoakan. Penggembalaan dalam pemeliharaan berperan penting terkait dengan pemeliharaan manusia, Pemeliharan merupakan sebuah dorongan dari hati setiap manusia yang 
muncul dalam melakukan segala kegiatan melalui pelayanan penggembalaan yang seutuhnya. Abineno menjelaskan bahwa pemeliharaan penggembalaan adalah kebutuhan manusia di mana manusia yang menerima atau memelihara pengalaman rohani dalam percakapan, kehidupan dan kebutuhan rohani sehari-hari (Hutagalung et al., 2021)

Beberapa manfaat pendampingan pastoral adalah meringankan beban penderitaan sesama, menempatkan manusia dalam relasi dengan Allah dan sesama dalam pengertian menumbuhkan dan membentuk manusia pada keutuhan dalam kehidupan spiritualnya (Agata, 2017). Pendampingan pastoral bisa berupa bimbingan konseling kepada kepada anggota jemaat. Salah satu faktor penting dalam proses konseling adalah trust atau kepercayaan dari yang mau dibimbing (konseli). Pendampingan pastoral melibatkan pembentukan hubungan khusus yang ditandai dengan keterbukaan dan kepercayaan (Redding, 2012). Konseling harus merebut kepercayaan publik (public trust), kepercayaan publik akan melanggengkan profesi konseling, karena dalam public trust terkandung keyakinan publik akan kompetensi konselor (Suryono, 2016).

Pada gambar 6 atau pernyataan ke 4 menunjukan bahwa 87,9\% responden setuju dan sangat setuju, "percaya pada nasehat dan bimbingan pendeta". hal ini sangat menunjang keberhasilan bimbingan konseling pada pelayanan pendampingan pastoral. Ini merupakan 
kekuatan bagi para pendamping pastoral: pendeta, penatua, guru jemaat dan anggota majelis jemaat.

Hasil penelitian ini membuktikan akan adanya kebutuhan pendampingan bagi mereka yang kecanduan game online. Hal itu terlihat pada angka $62,1 \%$ responden satuju dan sangat setuju, membutuhkan pendampingan pastoral. Di lain pihak, sudah menjadi tanggung jawab gereja dalam hal ini para pendeta, penatua, guru injil bahkan anggota majelis jemaat untuk hadir di setiap bagian kehidupan anggota-anggota jemaat dalam membimbing dan menggembalakan mereka, tidak terkecuali bagi mereka yang kecanduan game online.

\section{KESIMPULAN}

Pendampingan pastoral adalah satu pelayanan yang sangat penting dalam pemeliharaan kerohanian anggota gereja. Tugas ini merupakan bagian dari amanat agung dari Yesus Kristus dalam Matius 28:20 "dan ajarlah mereka melakukan segala sesuatu yang telah Kuperintahkan kepadamu..." Perintah ajarkanlah dapat juga dimaknai sebagai sebuah pembimbingan. Perintah Yesus yang lain juga mengatakan dalam Yohanes 21:15 “... Kata Yesus kepadanya: Gembalakanlah domba domba-Ku." Perintah ini ditujukan kepada Petrus, tapi perintah ini secara tidak langsung ditujukan juga kepada gereja.

Fenomena kecanduan game secara umum dan game online secara khusus, menjadi masalah bukan saja bagi masyarakat tetapi juga bagi 
warga gereja. Kesadaran sebagian besar responden tentang dampak buruk dari aktifitas game online dan keinginan untuk terlepas dari kecanduan tersebut, merupakan satu hal yang baik bagi penanganan masalah ini. Solusi yang ditemukan peneliti adalah dengan diadakanya pendampingan pastoral kepada anggota jemaat yang kecanduan aktifitas tersebut.

Adanya kebutuhan pendampingan pastoral dan kepecayaan yang tinggi kepada nasehat dan bimbingan pendeta merupakan temuan yang baru melalui hasil penelitian ini, yang berbeda dengan penelitian penelitian sebelumnya. Hal ini membuat peneliti menyimpulkan bahwa pendampingan pastoral itu sangat penting dilakukan, untuk menolong mereka yang terjebak dalam kecanduan game DAFonline.

Sebagai saran yang pertama adalah, gereja melalui pendeta, penatua, guru injil dan majelis jemaat untuk melakukan pelayanan pendampingan pastoral kepada mereka yang terjebak dalam kecanduan game pada umunya dan game online pada khususnya. Saran yang kedua adalah perlu diadakannya penelitian lanjutan terkait dengan hasil peneltian ini.

\section{DAFTAR PUSTAKA}

Agata, R. (2017). Kajian Pendampingan Pastoral Terhadap Perilaku Anak Sekolah Minggu Akibat Ketergantungan Penggunaan Gadget di Gereja Batak Karo Protestan Galaxi, Bekasi. Fakultas Teologi Universitas Kristen Satya Wacana Salatiga. 
Ali, Z., Dwikurnaningsih, Y., \& Setyorini, S. (2019). Pengaruh Dari Dampak Game Online Terhadap Motivasi Belajar pada Siswa Kelas VIII SMP Kristen 2 Salatiga. Genta Mulia: Jurnal IImiah Pendidikan, 10(1), 122133.

British, T., \& Society, N. (2000). Guidelines for Good Practice in Neuropathology. 1-7.

Haines, J. (2011). A Biblical Foundation To Pastoral Care .

Hermawan, E. (2019). Kecanduan Game Digital Online: Memahami Dampak Kecanduan Game Online Terhadap Hubungan Sosial. Kelola: Jurnal Sosial Politik, 2(1), 149-162. https://doi.org/10.15575/jk.v2i1.6629

Hutagalung, S. (2021). Pendampingan Pastoral: Teori dan Praktik (B. Purba (ed.)). Yayasan Kita Menulis.

Hutagalung, S., Bartholomeus, D. N., Hendrikks, A. C., Walukouw, Y. R., Hutabarat, R., Karosekali, E., Manurung, F., Sianipar, J. H., SImbolon, M., Hutabarat, M. S., \& Sagala, R. W. (2021). Konseling Pastoral. Yayasan Kita Menulis.

Januarharyono, Y. (2019). Peran Pemuda Di Era Globalisasi. Jimia: Jurnal IImiah Magister IImu Administrasi, 13(1), 9.

Kevaladandra, Z., \& Nurmala, I. (2019). Persepsi Kontrol Perilaku dalam Niat Berhenti Mengonsumsi Minuman Beralkohol pada Mahasiswa di Surabaya. Jurnal Keperawatan Muhammadiyah, 4(1), 74-80. https://doi.org/10.30651/jkm.v4i1.2071

Kurniawan, K. (2020). Konseling Pastoral Krisis Pada Remaja Yang Kecanduan Gadget. Fakultas Teologi Universitas Kristen Duta Wacana Yogyakarta.

Nofianti, L., \& Qomariah. (2017). Ringkasan Buku Metode Penelitian Survey. Universitas Islam Negeri Sultan Syarif Kasim Riau.

Novrialdy, E. (2019). Kecanduan Game Online pada Remaja: Dampak dan Pencegahannya. Buletin Psikologi, 27(2), 148. https://doi.org/10.22146/buletinpsikologi.47402

Nugroho, F. J. (2017). Pendampingan Pastoral Holistik: Sebuah Usulan Konseptual Pembinaan Warga Gereja. Evangelikal: Jurnal Teologi Injili dan Pembinaan Warga Jemaat, 1(2), 139. https://doi.org/10.46445/ejti.v1i2.71

Psychologymania. (2008). Definisi Kecanduan. PT. Nirmala Satya Development.

Redding, G. (2012). Pastoral Care Handbook. October, 50.

Setiawan, E. (2021). Kamus Besar Bahasa Indonesia (KBBI). KBBI 
Online.

Siswanto, D., Sagala, R., \& Hutagalung, S. (2021). Kekuatan dan Tantangan Pengajaran Kristen Tentang Pernikahan Dalam Perspektif Jemaat GMAHK Putra Agung Surabaya. Visio Dei: Jurnal Teologi Kristen, 3(1), 127-146. https://doi.org/10.35909/visiodei.v3i1.208

Sumarsih, T., \& Nugroho, F. A. (2020). Edukasi Dampak Negatif Bermain Game Online Dan Tontonan Kekerasan Pada Siswa Smp Muhammadiyah Gombong. Jurnal EMPATI: Edukasi Masyarakat, Pengabdian dan Bakti, $1(1), \quad 71$. https://doi.org/10.26753/empati.v111.411

Suryono, B. (2016). Public Trust dan Profesi BK Bermartabat Menuju Karakter Konselor Yang Dibutuhkan. Counsellia: Jurnal Bimbingan dan Konseling, 2(1). https://doi.org/10.25273/counsellia.v2i1.195

Tendean, J. J., Nainggolan, B. D., \& Hutagalung, S. (2021). Pandemic Covid-19, Health Literature and Great Commission Pandemi Covid 19, Literatur Kesehatan dan Amanat Agung. Journal Grafta: Journal Of Christian Religion Education And Biblical Studies, 1(1), 1-11.

Untari, D. T. (2018). Metodologi Penelitian: Penelitian Kontemporer Bidang Ekonomi dan Bisnis. https://doi.org/10.31237/osf.io/xp62v

White, E. G. (2015). Membina Anak Yang Bertanggung Jawab. Bandung: Indonesia Publishing House.

Wijayatsih, H. (2011). Pendampingan dan Konseling Pastoral. Gema Teologi, 35(1), 3-10. 